\title{
Phytoplankton chlorophyll $a$ biomass, composition, and productivity along a temperature and stratification gradient in the northeast Atlantic Ocean
}

\author{
W. H. van de Poll ${ }^{1}$, G. Kulk ${ }^{2}$, K. R. Timmermans ${ }^{1}$, C. P. D. Brussaard ${ }^{1}$, H. J. van der Woerd ${ }^{3}$, M. J. Kehoe ${ }^{4}$, \\ K. D. A. Mojica ${ }^{1}$, R. J. W. Visser ${ }^{2}$, P. D. Rozema ${ }^{2}$, and A. G. J. Buma ${ }^{2}$ \\ ${ }^{1}$ Department of Biological Oceanography, Royal Netherlands Institute for Sea Research (NIOZ), P.O. Box 59, 1790 AB, \\ Den Burg, the Netherlands \\ ${ }^{2}$ Department of Ocean Ecosystems, Energy and Sustainability Research Institute Groningen, University of Groningen, \\ Nijenborgh 7, 9747 AG Groningen, the Netherlands \\ ${ }^{3}$ Institute for Environmental Studies (IVM), VU University Amsterdam, De Boelelaan 1087, 1081 HV, Amsterdam, \\ the Netherlands \\ ${ }^{4}$ Institute for Biodiversity and Ecosystem Dynamics (IBED), University of Amsterdam, P.O. Box 94248, 1090 GE, \\ Amsterdam, the Netherlands
}

Correspondence to: W. H. van de Poll (w.h.van.de.poll@ rug.nl)

Received: 14 January 2013 - Published in Biogeosciences Discuss.: 31 January 2013

Revised: 2 May 2013 - Accepted: 19 May 2013 - Published: 25 June 2013

\begin{abstract}
Relationships between sea surface temperature $(\mathrm{SST},>10 \mathrm{~m})$ and vertical density stratification, nutrient concentrations, and phytoplankton biomass, composition, and chlorophyll $a$ (Chl $a$ ) specific absorption were assessed in spring and summer from latitudes 29 to $63^{\circ} \mathrm{N}$ in the northeast Atlantic Ocean. The goal of this study was to identify relationships between phytoplankton and abiotic factors in an existing SST and stratification gradient. Furthermore, a biooptical model was used to estimate productivity for five phytoplankton groups. Nutrient concentration (integrated from 0 to $125 \mathrm{~m}$ ) was inversely correlated with SST in spring and summer. SST was also inversely correlated with near-surface $(0-50 \mathrm{~m}) \mathrm{Chl} a$ and productivity for stratified stations. Nearsurface Chl $a$ and productivity showed exponential relationships with SST. Chl $a$ specific absorption and excess light experiments indicated photoacclimation to lower irradiance in spring as compared to summer. In addition, Chl $a$ specific absorption suggested that phytoplankton size decreased in summer. The contribution of cyanobacteria to water column productivity of stratified stations correlated positively with SST and inversely with nutrient concentration. This suggests that a rise in SST (over a $13-23{ }^{\circ} \mathrm{C}$ range) stimulates productivity by cyanobacteria at the expense of haptophytes, which
\end{abstract}

showed an inverse relationship to SST. At higher latitudes, where rising SST may prolong the stratified season, haptophyte productivity may expand at the expense of diatom productivity. Depth-integrated Chl $a(0-410 \mathrm{~m})$ was greatest in the spring at higher latitudes, where stratification in the upper $200 \mathrm{~m}$ was weakest. This suggests that stronger stratification does not necessarily result in higher phytoplankton biomass standing stock in this region.

\section{Introduction}

Phytoplankton growth in the oceans ultimately depends on seasonal and interannual climatological cycles that determine the availability of nutrients and light. In addition, loss factors such a grazing, viral lyses, and sinking influence phytoplankton standing stock. In the open ocean, vertical density stratification is an important process in shaping the resource availability for phytoplankton growth. Stabilization of the water column allows phytoplankton to exploit higher irradiance intensities near the surface. However, stratification also inhibits exchange with nutrient-rich deep water, potentially leading to nutrient limitation of phytoplankton near the surface. In 
the absence of stratification (winter, early spring) the depth range of vertical mixing due to wind and convection can expand by more than one order of magnitude, reducing phytoplankton light availability, and increasing nutrient concentrations. Furthermore, stratification may affect predator-prey and viral-algal host interactions by influencing encounter rates (Behrenfeld, 2010; Baudoux et al., 2008). Moreover, stratification is also an important factor in the seasonal development of phytoplankton composition in the open ocean. Changes in phytoplankton composition often coincide with changes in cell size, because an increased surface-to-volume ratio is advantageous under low nutrient concentrations typical of a stratified water column (Chisholm and Morel, 1991). High nutrient concentrations and turbulence due to winter mixing supports the growth of larger phytoplankton species such as diatoms, whereas the onset of stratification in spring leads to a succession towards smaller phytoplankton species (Litchman et al., 2007; Claustre et al., 2005). Low nutrient availability in the (sub)tropical oligotrophic ocean results in the dominance of cyanobacteria like Synechococcus and Prochlorococcus over picoeukaryotic phytoplankton species (Li, 1994; Johnson et al., 2006). The changes in phytoplankton composition can affect productivity and carbon storage to the deep ocean (Claustre et al., 2005; Martin et al., 2011).

Apart from pronounced seasonal changes, the North Atlantic experiences fluctuations in sea surface temperature (SST, $>10 \mathrm{~m}$ ) on interannual to multidecadal scales due to the influence of the North Atlantic Oscillation and the Atlantic Multidecadal Oscillation (changes in the range of $0.5^{\circ} \mathrm{C}$, Drinkwater et al., 2003; Enfield et al., 2001; Ting et al., 2009). In addition, the North Atlantic has experienced significant warming as a result of global climate change (Gleckler et al., 2012), and this process is expected to continue over the next decades. The response of ocean productivity to rising temperature is under debate. Models predict that increased SST will enhance stratification of the upper oceans (Steinacher et al., 2010; Hofmann et al., 2011), thereby reducing the depth of the mixed layer and decreasing nutrient exchange with the deep ocean. Remote-sensingderived, globally averaged $\mathrm{Chl} a$ and productivity showed a significant negative relationship with density differences in the upper oligotrophic open ocean (Behrenfeld et al., 2006; Polovina et al., 2008). However, long-term monitoring sites and historical records for estimated Chl $a$ showed conflicting trends for the North Atlantic and other oceanic regions (Chavez et al., 2010; Boyce et al., 2010). Furthermore, no evidence for the interannual control of phytoplankton biomass and productivity by stratification was observed in the subtropical North Pacific or North Atlantic, although stratification correlated on a seasonal timescale with phytoplankton productivity (Dave and Lozier, 2010; Lozier et al., 2011). At mid- and higher latitudes in the North Atlantic, stratification has been associated with bloom formation (Dutkiewicz et al., 2001). Here, termination of convection and the onset of stratification initiate the phytoplankton spring bloom (Siegel et al., 2002; Taylor and Ferrari, 2011; Mahadevan et al., 2012). Earlier onset of stratification in the subpolar North Atlantic may prolong the phytoplankton bloom season (Racault et al., 2012). As such, different responses to stratification can be expected between the subpolar and subtropical North Atlantic (Richardson and Schoeman, 2004).

We hypothesized that SST influences phytoplankton biomass and composition by affecting nutrient concentrations in the upper open ocean. Therefore, relationships between SST and nutrient concentrations can be expected along existing temperature gradients. Furthermore, relationships between SST, phytoplankton biomass, composition and productivity can be expected along existing temperature gradients in the open ocean. Recent studies on temperature and stratification relationships with phytoplankton biomass and productivity have focused on the oligotrophic open ocean, where nutrient limitation of phytoplankton is a dominant feature (Behrenfeld et al., 2006; Polovina et al., 2008; Dave and Lozier, 2010; Lozier et al., 2011). In this context, temperate and higher latitude regions have received less attention and studies that include both oligotrophic and higher latitude waters on this topic are currently lacking. A pronounced gradient in SST and stratification can be observed from low $\left(29^{\circ} \mathrm{N}\right)$ to higher $\left(63^{\circ} \mathrm{N}\right)$ latitudes in the North Atlantic (Jurado et al., 2012a,b). We investigated seasonal changes in biomass, productivity, and composition of North Atlantic phytoplankton along this gradient in relation to stratification, sea surface temperature, nutrient concentration, and light availability. Furthermore, a model was used to estimate daily water column productivity in the euphotic zone, using in situ phytoplankton biomass ( $\mathrm{Chl} a$ ), phytoplankton composition (pigments), light, and temperature as variables, providing insight into the contribution of five phytoplankton taxonomic groups to community primary productivity. Because stratification shows strong seasonality at temperate and higher latitudes, the gradient in the North Atlantic was sampled during spring when stratification was weak, and during summer when the strongest stratification occurs.

\section{Methods}

Two cruises were performed in the North Atlantic Ocean onboard the RV Pelagia covering the area between the Canary Islands and Iceland (summer: July/August 2009; spring: April/May 2011). The cruise track covered subtropical, temperate, and subpolar sections in the North Atlantic Ocean (Fig. 1). Samples were collected with a trace metal clean CTD (conductivity, temperature, depth) frame equipped with 12 (summer) and $27 \mathrm{~L}$ (spring) sample bottles. Samples for macronutrients, pigments, chlorophyll specific absorption, and excess light experiments (see below) were obtained in a dedicated clean container. 


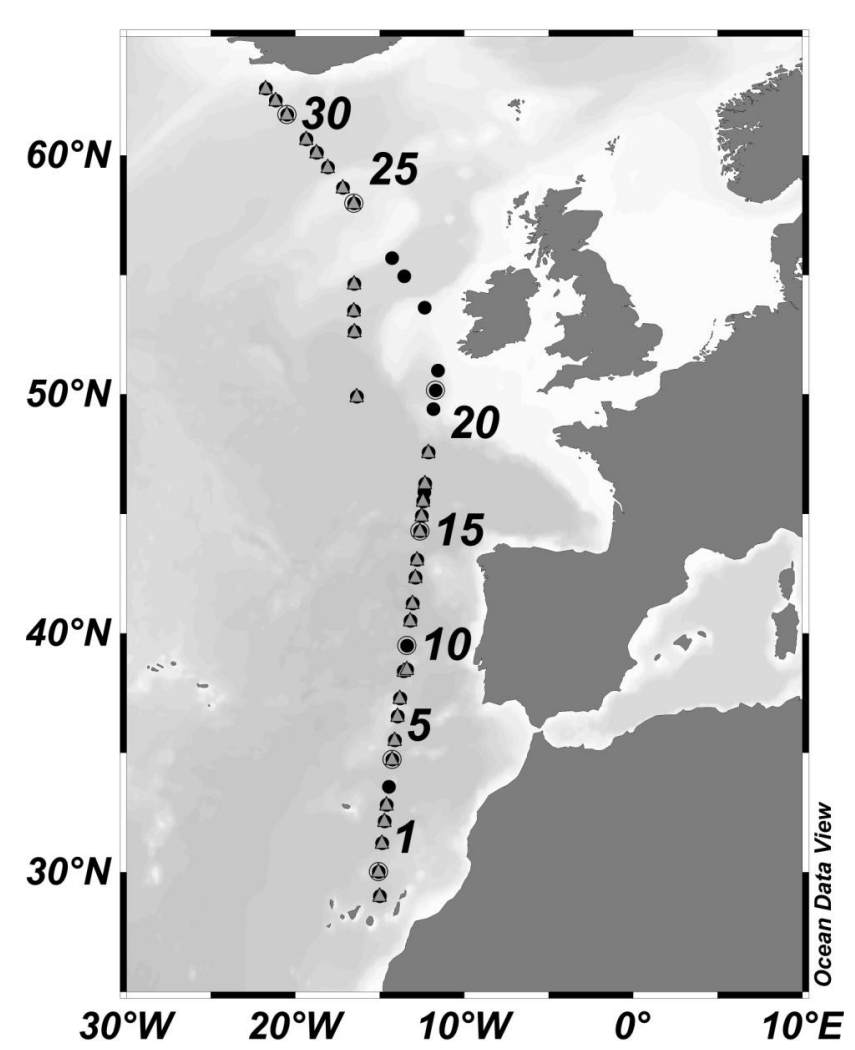

Fig. 1. Sample locations of the spring (2011, triangles) summer and (2009, circles) Stratiphyt cruises. The numbers represent the station numbers.

\subsection{Stratification index}

The stratification index (Behrenfeld et al., 2006; Dave and Lozier, 2010; Lozier et al., 2011) was used as a measure of stratification. The stratification index was calculated as the difference in potential density (sigma-theta) between the upper $10 \mathrm{~m}(0-10 \mathrm{~m}$ average $)$ and $200 \mathrm{~m}$ using the salinity and temperature profiles obtained by the CTD (Seabird 9+). When the difference in potential density was smaller than 0.125 , the upper $200 \mathrm{~m}$ was considered as non-stratified (De Boyer Montegut et al., 2004).

\subsection{Nutrients}

Nutrient samples $(6 \mathrm{~mL})$ were obtained from multiple bottles, sampling between 4 and 7 depths. The samples were filtered through $0.2 \mu \mathrm{m}$ Acrodisc filters and measured onboard for inorganic $\mathrm{PO}_{4}, \mathrm{NH}_{4}, \mathrm{NO}_{2}$, and $\mathrm{NO}_{2}+\mathrm{NO}_{3}$ using a Bran \& Luebbe Quaatro autoanalyzer. Depth profiles of $\mathrm{PO}_{4}$ and $\mathrm{NO}_{3}$ (calculated by subtracting $\mathrm{NO}_{2}$ from $\mathrm{NO}_{2}+\mathrm{NO}_{3}$ ) were fitted with a three or a five parameter sigmoidal function by nonlinear regression (Sigma plot 11.0). Using the obtained function, nutrient concentrations were calculated over one meter depth intervals for the potential $(0-125 \mathrm{~m})$, upper $(0-50 \mathrm{~m})$, and lower $(50-125 \mathrm{~m})$ euphotic zone. Further-

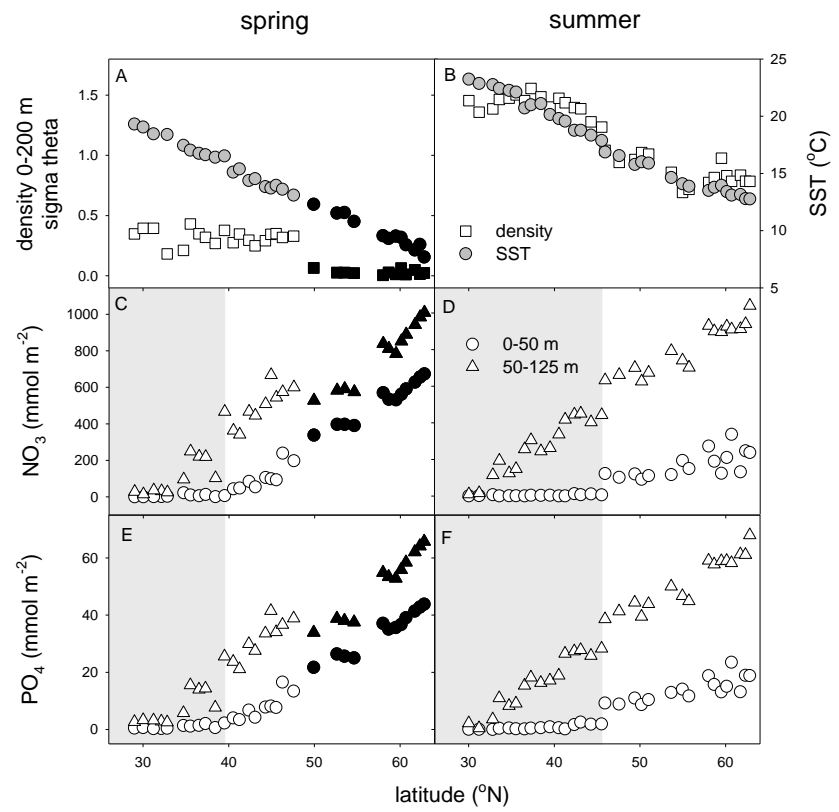

Fig. 2. Latitudinal changes in abiotic data from the spring (A, C, E) and summer $(\mathbf{B}, \mathbf{D}, \mathbf{F})$ cruises. (A, B) Density differences in the upper $200 \mathrm{~m}$ and sea surface temperature (SST, secondary yaxis). (C, D) Depth-integrated nitrate $\left(\mathrm{NO}_{3}\right)$ concentration in the upper (0-50 m) and lower (50-125 m) euphotic zone. (E, F) Depthintegrated inorganic phosphate $\left(\mathrm{PO}_{4}\right)$ concentration in the upper $(0-50 \mathrm{~m})$ and lower $(50-125 \mathrm{~m})$ euphotic zone. Black symbols represent data from non-stratified stations. The gray area indicates regions with oligotrophic conditions.

more, $\mathrm{N}: \mathrm{P}$ ratios were calculated for the upper and lower euphotic zone as $\left(\mathrm{NO}_{3}+\mathrm{NH}_{4}\right) / \mathrm{PO}_{4}$ for the respective depth intervals. In the present study, oligotrophic and mesotrophic stations were distinguished based on the concentration of $\mathrm{NO}_{3}$ in the upper euphotic zone $(0-50 \mathrm{~m})$. We defined oligotrophic stations as those stations where $\mathrm{NO}_{3}$ in the upper euphotic zone was below the detection limit $\left(0.13 \mu \mathrm{mol} \mathrm{L}^{-1}\right)$, whereas nutrients were detectable in the upper euphotic zone of mesotrophic stations (Fig. 2). The detection limit for $\mathrm{PO}_{4}$ was $0.03 \mu \mathrm{mol} \mathrm{L} \mathrm{L}^{-1}$.

\subsection{Chlorophyll specific absorption}

Samples (5-10L) for Chl $a$ specific absorption were obtained from the chlorophyll maximum (oligotrophic stations: $\sim 70 \mathrm{~m}$; mesotrophic stations: $\sim 40 \mathrm{~m}$ ) and from the subsurface (oligotrophic stations: $\sim 15$ to $30 \mathrm{~m}$; mesotrophic stations: $\sim 10$ to $15 \mathrm{~m}$ ). The samples were filtered through $47 \mathrm{~mm} \mathrm{GF/F} \mathrm{(Whatman),} \mathrm{frozen} \mathrm{in} \mathrm{liquid} \mathrm{nitrogen,} \mathrm{and}$ stored at $-80^{\circ} \mathrm{C}$. Transmission and reflection from the filter was measured between 350 and $800 \mathrm{~nm}$ on a Varian CARY 3E UV/VIS double beam spectrophotometer with integrating sphere over $1 \mathrm{~nm}$ intervals, before and after bleaching with $1 \%$ sodium hypochloride (Tassan and Ferrari, 1995). Chlorophyll specific absorption $\left(a_{\mathrm{ph}}\right)$ was calculated between 
400 and $700 \mathrm{~nm}$ using the filter clearance area, sample volume, Chl $a$ concentration (separate high-performance liquid chromatography sample, see below), and the amplification factor $\beta$ (set at 2 for all samples). The spectrally weighted mean specific absorption coefficient $\left(=\bar{a}^{*}\right)$ was calculated as the sum of $\bar{a} *_{\mathrm{ph}}$ between 400 and $700 \mathrm{~nm}$ and corrected by a normalized solar spectrum (maximum set to one). Changes in light spectrum with depth were not accounted for. The spectrally weighted mean specific absorption coefficient $\left(\bar{a}^{*}\right)$ was used to indicate the presence of differences in species composition and photoacclimation between samples from different depths for the CHEMTAX calculations (see below).

\subsection{Excess light experiments}

An experimental approach was used to obtain information on the photoacclimation state of phytoplankton, which was used for the productivity calculations. Samples from discrete depths (chlorophyll maximum and subsurface) were exposed to excess irradiance, and fluorescence characteristics were determined during recovery in low light. Previous studies demonstrated that this response is strongly dependent on the photoacclimation state of algae (Van de Poll et al., 2006, 2011). Phytoplankton samples were exposed in $350 \mathrm{~mL}$ quartz cuvettes to $5 \mathrm{~min}$ of excess light (provided by a $250 \mathrm{~W}$ MHN-TD lamp (Philips) and two $20 \mathrm{~W}$ TL/12 lamps (Philips)) at in situ temperature. PAR and PAR+UVR conditions were created with GG395 and WG305 filters (Schott AG, Mainz), respectively (Supplement, Table 6). $30 \mathrm{~mL}$ subsamples from the cuvettes were obtained after exposure and during recovery in low light at $5 \mathrm{~min}$ intervals for $60 \mathrm{~min}$. Control samples $(150 \mathrm{~mL})$ remained in darkness (dark-adapted controls). Fluorescence parameters were determined using a Water PAM with a WATER-FT flow-through emitter-detector (Waltz, $\mathrm{GmbH}$ ). Recovery of PSII quantum yield was determined by comparing the maximum PSII quantum yield (dark acclimated) with the average PSII quantum yield that was reached between 40 and $60 \mathrm{~min}$ of recovery after exposure. Because fast reversible non-photochemical quenching relaxes within $40 \mathrm{~min}$, this provides an indication for slowly reversible photoinhibition (i.e., damage that requires a relatively long time to repair). The maximum quantum yield of PSII $\left(F_{v} / F_{m}\right)$ was calculated as $\left(F_{m}-F_{0}\right) / F_{m}$.

\subsection{Pigment composition}

Four to seventeen samples (5-10L) were obtained from multiple depths at each station and filtered through $47 \mathrm{~mm}$ $\mathrm{GF} / \mathrm{F}$ filters (Whatman) under mild vacuum $(0.3 \mathrm{mbar})$, frozen in liquid nitrogen, and stored at $-80^{\circ} \mathrm{C}$. Prior to analysis, filters were freeze dried $(48 \mathrm{~h})$ and pigments were extracted in $90 \%$ acetone $(v / v)\left(48 \mathrm{~h}, 4{ }^{\circ} \mathrm{C}\right.$, darkness). Pigments were separated on a Waters 2695 HPLC (high-performance liquid chromatography) system using a Zorbax Eclipse XDB-C8 column $(3.5 \mu \mathrm{m}$ particle size) as described by Hooker et al. (2009). Diode array spectroscopy (Waters 996) and retention time were used for pigment identification, and the system was calibrated against standards (DHI, Denmark) for chlorophyll $a 1$, divinyl (dv) chlorophyll $a 2$, chlorophyll $b$, chlorophyll $c 2$, chlorophyll $c 3$, peridinin, 19-butanoyloxyfucoxanthin, 19-hexanoyloxyfucoxanthin, fucoxanthin, neoxanthin, prasinoxanthin, alloxanthin, and zeaxanthin. Total $\mathrm{Chl} a$ (sum of Chl $a 1$ and dv Chl $a$ ) obtained from HPLC analysis served as a phytoplankton biomass indicator and was used to calibrate the fluorescence sensor from the CTD (Chelsea Aquatracka Mk III). A single relationship between HPLC Chl $a$ and Chl $a$ fluorescence values was used for the summer cruise. However, during the spring cruise, the relationship between $\mathrm{Chl} a$ fluorescence and HPLC Chl $a$ was more variable, and three different relationships were used to calibrate the fluorescence profiles for data from latitude 29 to $40^{\circ} \mathrm{N}, 40$ to $47^{\circ} \mathrm{N}$, and 48 to $63^{\circ} \mathrm{N}$. The calibrated fluorescence profiles were then used to calculate $\mathrm{Chl} a$ over $1 \mathrm{~m}$ depth intervals. Depth-integrated Chl $a$ was calculated for the euphotic zone and for defined depth intervals - Chl $a$ integrated over 0 $50 \mathrm{~m}\left(\mathrm{Chl} a_{0-50 \mathrm{~m}}\right)$ and total depth-integrated Chl $a$ (surface to $200-410 \mathrm{~m}$, Chl $a_{t}$ ). For the latter, Chl $a$ below these depths was negligible. The euphotic zone was defined as the depth with $0.1 \%$ of surface irradiance. We choose the $0.1 \%$ depth as the limit of the euphotic zone because this is a better representation of the depth below which net photosynthesis is negligible than the commonly used $1 \%$ depth of surface irradiance. The $0.1 \%$ light depth was calculated from the vertical attenuation coefficient $\left(K_{\mathrm{d}}\right)$, which was determined from the linear regression of natural log transformed PAR vs. depth (PAR: photosynthetically active radiation, $400-700 \mathrm{~nm}$, measured by a $2 \pi$ Satlantic PAR sensor on the CTD).

\subsection{Phytoplankton composition}

Phytoplankton taxonomic composition was determined using CHEMTAX (Mackey et al., 1996) and will be presented in Mojica et al. (2013). In short, 13 pigments (Chl $a$, dv Chl $a$, Chl $b$, Chl $c 2$, Chl $c 3$, peridinin, fucoxanthin, 19butanoyloxyfucoxanthin, 19-hexanoyloxyfucoxanthin, neoxanthin, prasinoxanthin, alloxanthin, and zeaxanthin) were used to distinguish 8 taxonomic groups (cyanobacteria: Synechococcus and Prochlorococcus, haptophytes, diatoms, dinoflagellates, cryptophytes, prasinophytes, and pelagophytes). Samples were grouped according to latitude and analyzed for spring and summer separately to minimize the residual error. In oligotrophic waters, Chl $a$ specific absorption showed differences between subsurface samples and those from the chlorophyll maximum. In accordance, separate CHEMTAX analyses were performed for oligotrophic samples with depth $<50 \mathrm{~m}$ and $>50 \mathrm{~m}$, using high-lightand low-light-acclimated initial pigment ratios, respectively (Supplement, Tables 3 and 4). Mesotrophic stations showed 
no differences between subsurface and chlorophyll maximum Chl $a$ specific absorption, and for these stations, lowlight-acclimated pigment ratios were used for all depths. Contributions of the taxonomic groups were expressed relative to Chl $a$. Initial pigment ratios for CHEMTAX (Supplement, Tables 3, 4) were obtained from published pigment ratios (Zapata et al., 2004; Laviale and Neveux, 2011; Kulk et al., 2011, 2012) and from exponentially growing batch cultures (haptophytes: Emiliania huxleyi, Phaeocystis globosa; and diatoms: Ditylum brightwellii, Thalassiosira pseudonana; unpublished results). CHEMTAX results were compared with light microscopy on fixed samples (Supplement), and with detailed flow cytometry data (Mojica et al., 2013). The current study focused on five phytoplankton groups used in the primary production model.

\subsection{Primary production}

Depth-integrated daily primary production in the euphotic zone $\left(\mathrm{PP}_{\mathrm{Zeu}}\right)$ and in the upper $50 \mathrm{~m}\left(\mathrm{PP}_{0-50 \mathrm{~m}}\right)$ was calculated for each station using a diagnostic bio-optical model comparable to Claustre et al. (2005) and Uitz et al. (2008). The model uses in situ temperature, light, light attenuation, and Chl $a$ profiles to estimate primary productivity of different oceanic phytoplankton groups. In contrast to the model presented by Claustre et al. (2005) and Uitz et al. (2008), the current model uses CHEMTAX based taxonomic groups and laboratory determined primary production rates. We used the recovery of PSII maximum quantum yield from excess light as a measure for phytoplankton photoacclimation state.

\subsubsection{In situ data and light}

In situ measurements obtained during the two cruises in the North Atlantic Ocean were used to set the irradiance climate, temperature, and biomass in the model. The daily light dose at each station was obtained from the Moderate Resolution Imaging Spectroradiometer (MODIS-Aqua) satellite (level 3 data, 9 d average) using photosynthetically available radiation (MAMO_PAR_9 $\mathrm{km} . \mathrm{CR}$ ), with $9 \mathrm{~km}^{-2}$ resolution from Giovanni ocean color radiometry portals. The time resolved surface PAR was then calculated using the formulations for the diurnal variation of solar irradiance from Kirk et al. (1994). PAR attenuation for $1 \mathrm{~m}$ depth intervals was calculated using the $K_{\mathrm{d}}$ determined from PAR profiles of the CTD (Supplement).

The in situ SST (CTD temperature at $10 \mathrm{~m}$ depth) during the spring and summer cruise in the North Atlantic Ocean ranged from 7.7 to $23.3^{\circ} \mathrm{C}$. Because carbon fixation characteristics for the model were based on laboratory measurements at $20^{\circ} \mathrm{C}$, a temperature correction was applied. A linear relationship between carbon fixation and temperature was assumed (-0.045 $\left.\mathrm{mg} \mathrm{C} \mathrm{m}^{-2} \mathrm{~d}^{-1}{ }^{\circ} \mathrm{C}^{-1}\right)$.
Phytoplankton biomass ( $\mathrm{Chl} a$ ) was obtained from in situ fluorescence profiles ( $1 \mathrm{~m}$ depth intervals), which were calibrated to HPLC Chl $a$ concentrations as described above.

\subsubsection{Primary production calculations}

Five groups were distinguished to model primary production: group 1: Prochlorococcus; group 2: Synechococcus; group 3: Prasinophyceae, Pelagophyceae, and Cryptophyceae; group 4: Haptophyceae and Dinophyceae; and group 5: diatoms. Photosynthetic characteristics for these functional groups were obtained from ${ }^{14} \mathrm{C}$-based photosynthesis versus irradiance measurements of Prochlorococcus marinus (group 1), Synechococcus sp. (group 2), Ostreococcus sp. (group 3), Emiliania huxleyi (group 4), and Thalassiosira oceanica (group 5) (Kulk et al., 2011). Photosynthetic characteristic of low light $\left(50 \mu \mathrm{mol}\right.$ photons $\left.\mathrm{m}^{-2} \mathrm{~s}^{-1}\right)$ and high light $\left(125 \mu \mathrm{mol}\right.$ photons $\left.\mathrm{m}^{-2} \mathrm{~s}^{-1}\right)$ acclimated phytoplankton were used to calculate carbon fixation rates (Supplement, Table 1). A vertical structure in photosynthetic characteristics was assumed during summer. The depth where the PAR dose exceeded the dose experienced by the high-lightacclimated cultures $\left(125 \mu \mathrm{mol}\right.$ photons $\left.\mathrm{m}^{-2} \mathrm{~s}^{-1}\right)$ was calculated from the $K_{\mathrm{d}}$. Above this depth, phytoplankton were assumed to be high-light acclimated, whereas low-lightacclimated phytoplankton $\left(50 \mu \mathrm{mol}\right.$ photons $\left.\mathrm{m}^{-2} \mathrm{~s}^{-1}\right)$ were assumed below this depth. In contrast, all phytoplankton was assumed to be low-light acclimated in spring. This was based on the Chl $a$ specific absorption and photoacclimation experiments that indicated low-light-acclimated phytoplankton and less vertical structure in the water column in spring. Depth-integrated primary production was calculated according to Platt et al. (1980; see Supplement) for a $24 \mathrm{~h}$ period over $1 \mathrm{~h}$ time intervals in the euphotic zone ( $0.1 \%$ PAR) for the five functional phytoplankton groups.

\subsection{Statistics}

Relationships between nutrient concentration $\left(\mathrm{NO}_{3}\right.$ and $\mathrm{PO}_{4}$ integrated over $0-125 \mathrm{~m}: \mathrm{N}_{0-125 \mathrm{~m}}$ and $\left.\mathrm{P}_{0-125 \mathrm{~m}}\right), \mathrm{SST}$, density differences $(0-200 \mathrm{~m})$, phytoplankton biomass, and phytoplankton productivity were assessed by calculating the Spearman rank-order correlation coefficient (SigmaPlot 11.0, Systat Software). We used the following indicators for phytoplankton biomass: Chl $a$ concentration in samples from 10 to $20 \mathrm{~m}$ (surface $\mathrm{Chl} a$ ), Chl $a$ integrated over 0 $50 \mathrm{~m}\left(\mathrm{Chl} a_{0-50 \mathrm{~m}}\right)$, and total depth-integrated Chl $a$ (surface down to $200-410 \mathrm{~m}$, Chl $a_{t}$ ). The daily integrated productivity in the euphotic zone $\left(\mathrm{PP}_{\mathrm{Zeu}}\right)$ and the daily productivity integrated over $0-50 \mathrm{~m}\left(\mathrm{PP}_{0-50 \mathrm{~m}}\right)$ were used as measures for productivity. In addition, relationships between contributions of five taxonomic groups to productivity were assessed. Summer and spring cruises were tested separately $(n=$ 32). Furthermore, relationships were assessed for stratified (spring and summer cruise pooled, $n=52$ ) and non-stratified 
Table 1. Spearman rank-order correlation coefficients of sea surface temperature (SST) and density differences in the upper $200 \mathrm{~m}$ (density) for nitrate $(\mathrm{N})$ and inorganic phosphate $(\mathrm{P})$ concentration in the potential euphotic zone $(0-125 \mathrm{~m})$. Data are shown for spring and summer cruises $(n=32)$ and for stratified $(n=52)$ and non-stratified $(n=12)$ stations from both cruises combined. Significant correlations are bold.

\begin{tabular}{lcccccccc}
\hline & \multicolumn{2}{c}{ Summer } & \multicolumn{2}{c}{ Spring } & \multicolumn{2}{c}{ Stratified } & \multicolumn{2}{c}{ Non-stratified } \\
& SST & Density & SST & Density & SST & Density & SST & Density \\
\hline $\mathrm{N}_{(0-125 \mathrm{~m})}$ & $\mathbf{- 0 . 9 9}$ & $\mathbf{- 0 . 8 7}$ & $\mathbf{- 0 . 9 9}$ & $\mathbf{- 0 . 7 5}$ & $\mathbf{- 0 . 8 4}$ & -0.10 & $\mathbf{- 0 . 9 1}$ & -0.24 \\
$\mathrm{P}_{(0-125 \mathrm{~m})}$ & $\mathbf{- 0 . 9 9}$ & $\mathbf{- 0 . 8 6}$ & $\mathbf{- 0 . 9 8}$ & $\mathbf{- 0 . 7 4}$ & $\mathbf{- 0 . 8 4}$ & -0.10 & $\mathbf{- 0 . 9 7}$ & -0.35 \\
\hline
\end{tabular}

(spring, $n=12$ ) stations. Chl $a$ specific absorption data from oligotrophic and mesotrophic stations were pooled (subsurface and Chl $a$ maximum, separately) and tested with a one-way ANOVA using Statistica 8.0 (StatSoft). Differences were considered significant at $p<0.05$.

\section{Results}

\subsection{Vertical density stratification}

In summer, all stations were stratified, whereas weaker stratification was found in spring (Fig. 2). In spring, the upper $200 \mathrm{~m}$ of the 12 stations above $47^{\circ} \mathrm{N}$ were considered to be non-stratified (density difference $<0.125$ ). In both seasons, the stratification index was highest at low latitudes and declined at higher latitudes, but the latitudinal gradient was less pronounced in spring compared to summer. The correlation between the stratification index (difference in potential density between the surface and $200 \mathrm{~m})$ and SST $(<10 \mathrm{~m})$ was stronger in summer than in spring (correlation coefficient 0.87 vs. 0.78 , data not shown).

\subsection{Nutrient standing stock}

Oligotrophic conditions were encountered up to latitude $45^{\circ} \mathrm{N}$ in summer and $39^{\circ} \mathrm{N}$ in spring. $\mathrm{N}$ and $\mathrm{P}$ concentrations in the lower euphotic zone (50-125 m) increased linearly with latitude and did not show significant differences between spring and summer (Fig. 2). $\mathrm{N}$ and $\mathrm{P}$ in the upper euphotic zone $(0-50 \mathrm{~m})$ of mesotrophic stations increased with latitude, and concentrations were higher in spring than in summer. $\mathrm{N}_{0-125 \mathrm{~m}}$ and $\mathrm{P}_{0-125 \mathrm{~m}}$ showed strong inverse correlations with SST in spring and summer and for stratified (summer and spring combined) and non-stratified stations (Table 1). The correlations between stratification index and $\mathrm{N}_{0-125 \mathrm{~m}}$ and $\mathrm{P}_{0-125 \mathrm{~m}}$ were stronger in summer than in spring and were not significant for stratified (summer and spring combined) and non-stratified stations. Integrated $\mathrm{N}$ and $\mathrm{P}$ concentrations in the euphotic zone were on average five times higher in non-stratified stations compared to stratified stations (data not shown).

Average $\mathrm{N}: \mathrm{P}$ ratios for the upper euphotic zone of oligotrophic stations were $9.6( \pm 3.6)$ and $12.0( \pm 6.2)$ for spring and summer, respectively (data not shown). Four olig-

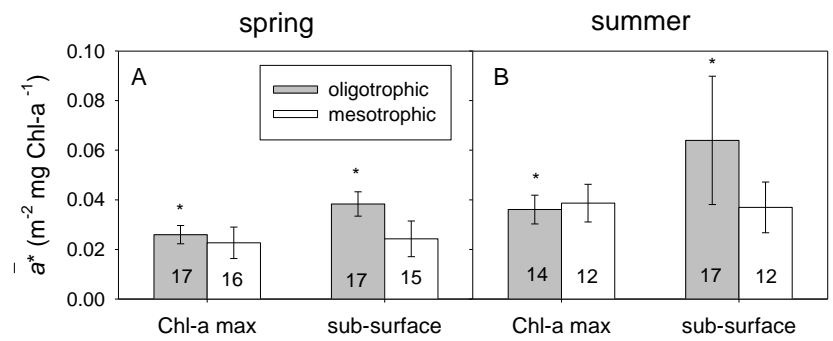

Fig. 3. The spectrally weighted mean specific absorption coefficient $\left(\bar{a}^{*}\right)$ for the chlorophyll maximum (Chl $a$ max) and subsurface samples for oligotrophic and mesotrophic stations, obtained during the spring (A) and summer (B) cruises (average \pm standard deviation). The number of replicates is indicated in the bars. Significant differences between chlorophyll maximum and subsurface samples are indicated with *.

otrophic stations showed high $\mathrm{N}: \mathrm{P}$ ratios due to extremely low $\mathrm{P}$ concentrations and were excluded from the $\mathrm{N}: \mathrm{P}$ calculations. At mesotrophic stations, the average $\mathrm{N}: \mathrm{P}$ ratio of the upper euphotic zone was $15.3( \pm 0.9)$ and 13.2 $( \pm 1.4)$ for spring and summer. Average N:P ratios for the lower euphotic zone were $14.0( \pm 3.7)$ and $16.5( \pm 0.9)$ for spring and summer in oligotrophic stations, and $15.9( \pm 0.6)$ and $16.1( \pm 0.3)$ for spring and summer in mesotrophic stations, respectively.

\subsection{Phytoplankton Chl $a$ specific absorption}

At oligotrophic stations, the spectrally weighted mean specific absorption coefficient $\left(\bar{a}^{*}\right)$ was significantly $(p<0.01)$ higher in samples from the subsurface compared to the chlorophyll maximum in spring and summer (Fig. 3). In mesotrophic stations, $\bar{a}^{*}$ was not different between samples from the subsurface and chlorophyll maximum in spring and summer. Chl $a$ specific absorption was on average $37 \%$ lower in spring compared to summer $(p<0.001)$.

\subsection{Excess light experiments}

Maximum quantum yield of dark-acclimated samples showed no significant difference between summer and spring (average of 0.628 and 0.636 in summer and spring, respectively). PSII quantum yield showed a strong response to excess light, but this initial response was not different for PAR 


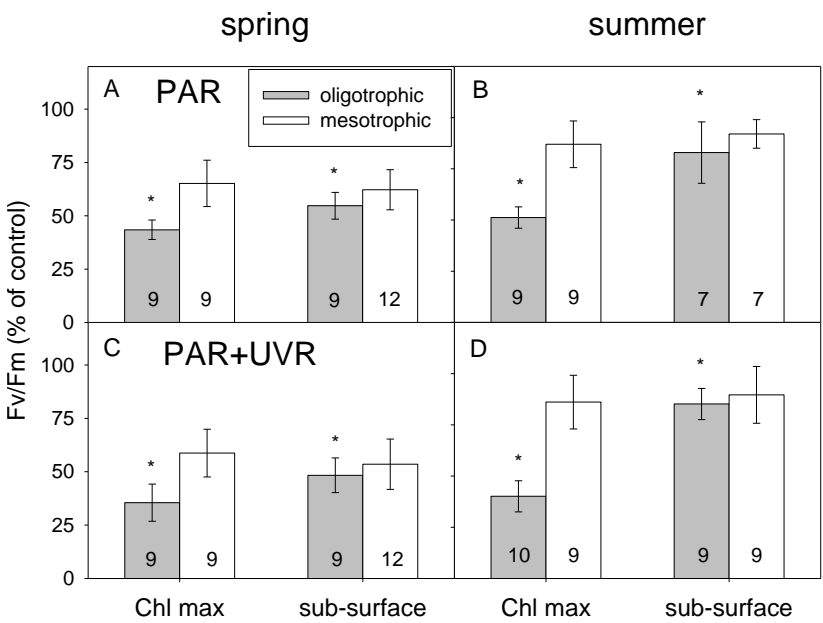

Fig. 4. Recovery of Fv/Fm (maximum quantum yield of PSII, \% of control) after excess PAR (A, B) and PAR + UVR (C, D) exposure. Samples were obtained from the subsurface and chlorophyll maximum, exposed to excess light, and Fv/Fm was monitored during recovery in low light. The recovery values between 40 and $60 \mathrm{~min}$ were averaged. The graphs show the average and standard deviation, the number of replicates is indicated in the bars. Significant differences between chlorophyll maximum and subsurface samples are indicated with *.

and PAR+UVR and was not significantly different among stations (results not shown). In contrast, recovery from excess light showed significant differences between summer and spring samples. Subsurface samples recovered to $90 \%$ of the original value within $1 \mathrm{~h}$ in summer, whereas this was $65 \%$ in spring, suggesting low irradiance acclimation in spring (Fig. 4). Chlorophyll maximum samples from oligotrophic stations showed significantly less recovery in spring and summer (40-50\% of original value, Fig. 4). PAR+UVR caused lower recovery in oligotrophic stations of chlorophyll maximum samples compared to PAR, but UVR effects were not significant in mesotrophic stations in both seasons.

\subsection{Phytoplankton biomass}

Oligotrophic stations showed a deep chlorophyll maximum, whereas surface $\mathrm{Chl} a$ was lower than that of mesotrophic stations. Mean surface Chl $a$ was higher in spring $\left(0.23 \pm 0.07 \mathrm{mg} \mathrm{Chl} a \mathrm{~m}^{-3}\right)$ than in summer $(0.08 \pm 0.03 \mathrm{mg}$ $\mathrm{Chl} a \mathrm{~m}^{-3}$ ) for oligotrophic stations (Fig. 5). More variability in surface Chl $a$ was observed in mesotrophic stations, with maximum surface concentrations $\left(2.0 \mathrm{mg} \mathrm{Chl} a \mathrm{~m}^{-3}\right)$ at midlatitudes during spring and at higher latitudes during the summer. Mean depth-integrated Chl $a\left(\mathrm{Chl} a_{t}\right.$ ) for oligotrophic stations was $49 \pm 11$ and $23 \pm 6 \mathrm{mg} \mathrm{Chl} a \mathrm{~m}^{-2}$ for spring and summer, respectively. Stronger seasonal differences were found in Chl $a_{t}$ of mesotrophic stations, with on average $112 \pm 36$ and $33 \pm 11 \mathrm{mg} \mathrm{Chl} a \mathrm{~m}^{-2}$ in spring and summer, respectively. Non-stratified stations showed high-

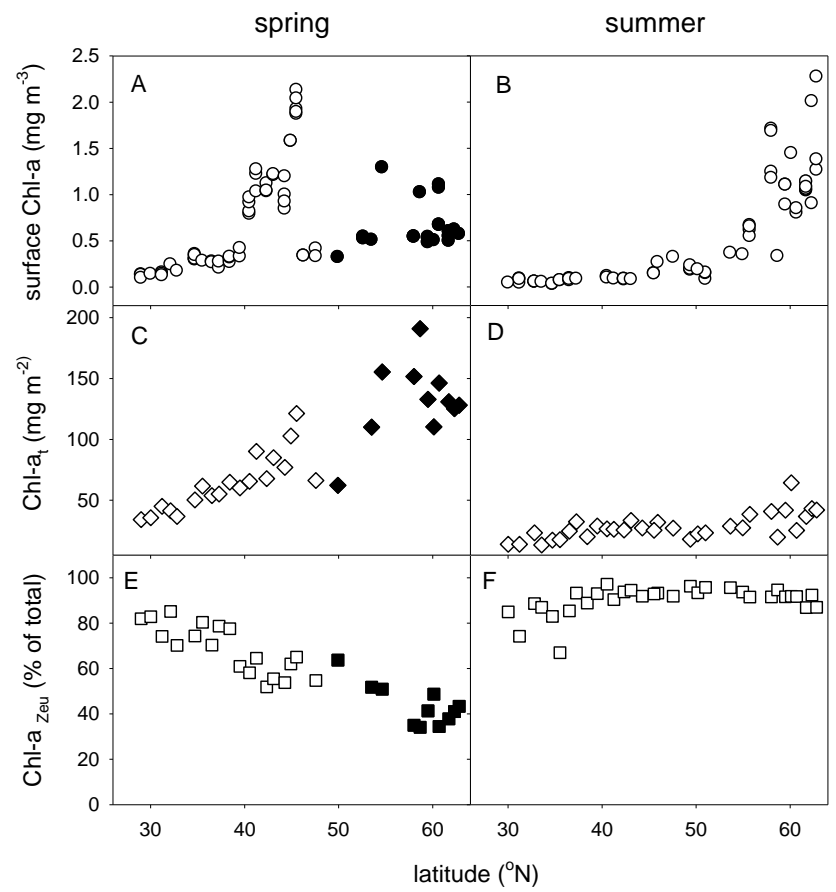

Fig. 5. Latitudinal changes in biomass (chlorophyll $a$ ) for the spring $(\mathbf{A}, \mathbf{C}, \mathbf{E})$ and summer $(\mathbf{B}, \mathbf{D}, \mathbf{F})$ cruise. $(\mathbf{A}, \mathbf{B})$ Surface Chl $a$ (samples from 10 to $20 \mathrm{~m}$ ) determined by HPLC. (C, D) Depthintegrated $\mathrm{Chl} a\left(\mathrm{Chl} a_{t}\right)$ as determined from HPLC-calibrated CTD fluorescence profiles from the surface to $200-410 \mathrm{~m}$. (E, F) Percentage of Chl $a$ in the euphotic zone ( $0.1 \%$ light depth). Black symbols represent data from non-stratified stations.

est Chl $a_{t}$ (up to $190 \mathrm{mg} \mathrm{Chl} a \mathrm{~m}^{-2}$, integrated over $410 \mathrm{~m}$ ). Depth-integrated Chl $a$ in the euphotic zone declined with increasing latitude from 80 to $30 \%$ in spring, whereas $90 \%$ of Chl $a$ was found in the euphotic zone in summer (Fig. 5). In spring, Chl $a$ in the euphotic zone correlated positively with SST (correlation coefficient 0.92), but not in summer. Surface Chl $a$ and Chl $a_{0-50 \mathrm{~m}}$ correlated with $\mathrm{N}_{0-125 \mathrm{~m}}$ and $\mathrm{P}_{0-125 \mathrm{~m}}$, whereas inverse correlations were observed with SST (Table 2, Fig. 6). Correlations between these variables were weaker in spring compared to summer. In spring, Chl $a_{t}$ correlated with $\mathrm{N}_{0-125 \mathrm{~m}}$ and $\mathrm{P}_{0-125 \mathrm{~m}}$, SST, and the stratification index. When tested for stratified stations (spring and summer combined), surface Chl $a$ and $\mathrm{Chl} a_{0-50 \mathrm{~m}}$ showed significant inverse correlations with SST and stratification index, and positive correlations with $\mathrm{N}_{0-125 \mathrm{~m}}$ and $\mathrm{P}_{0-125 \mathrm{~m}}$ (Table 2). The relationships between $\mathrm{Chl} a$ (surface $\mathrm{Chl} a$ and $\mathrm{Chl} a_{0-50 \mathrm{~m}}$ ) and SST were best described by an exponentially declining function (Fig. 6). Chl $a$ concentrations of non-stratified stations were not correlated with $\mathrm{N}_{0-125 \mathrm{~m}}$ and $\mathrm{P}_{0-125 \mathrm{~m}}$, SST, and stratification index (data not shown). 
Table 2. Spearman rank-order correlation coefficients of nitrate $(\mathrm{N})$ and inorganic phosphate $(\mathrm{P})$ concentrations in the potential euphotic zone (0-125 m), sea surface temperature (SST), and density differences in the upper $200 \mathrm{~m}$ (density) versus phytoplankton biomass and productivity. Surface chlorophyll $a$ (surface Chl $a$ ), Chl $a$ in the upper euphotic zone ( $\mathrm{Chl} a_{0-50 \mathrm{~m}}$ ), and $\mathrm{Chl} a$ integrated from the surface to $200-410 \mathrm{~m}\left(\mathrm{Chl} a_{t}\right)$ were used as biomass indicators. Productivity in the upper euphotic zone $\left(\mathrm{PP}_{0-50 \mathrm{~m}}\right)$ and productivity in the euphotic zone $\left(\mathrm{PP}_{\mathrm{Zeu}}\right)$ were used as indicators for productivity. Data are shown for spring and summer cruises $(n=32)$, and for the stratified stations from both cruises $(n=52)$. Significant correlations are expressed in bold.

\begin{tabular}{|c|c|c|c|c|c|}
\hline & & $\mathrm{N}_{(0-125 \mathrm{~m})}$ & $\mathrm{P}_{(0-125 \mathrm{~m})}$ & SST & Density \\
\hline \multirow{5}{*}{$\begin{array}{l}\text { Summer } \\
n=32\end{array}$} & Surface Chl $a$ & 0.95 & 0.95 & -0.96 & -0.86 \\
\hline & Chl $a_{0-50 \mathrm{~m}}$ & 0.92 & 0.92 & -0.92 & -0.83 \\
\hline & Chl $a_{t}$ & 0.66 & 0.66 & -0.66 & -0.51 \\
\hline & $\mathrm{PP}_{0-50 \mathrm{~m}}$ & 0.88 & 0.89 & -0.89 & -0.84 \\
\hline & $\mathrm{PP}_{\mathrm{Zeu}}$ & 0.87 & 0.88 & -0.87 & $-\mathbf{0 . 8 3}$ \\
\hline \multirow{5}{*}{$\begin{array}{l}\text { Spring } \\
n=32\end{array}$} & Surface Chl $a$ & 0.59 & 0.59 & -0.61 & -0.34 \\
\hline & Chl $a_{0-50 \mathrm{~m}}$ & 0.41 & 0.40 & -0.41 & -0.05 \\
\hline & $\mathrm{Chl} a_{t}$ & 0.89 & 0.89 & -0.91 & -0.72 \\
\hline & $\mathrm{PP}_{0-50 \mathrm{~m}}$ & 0.43 & 0.44 & -0.47 & -0.17 \\
\hline & $\mathrm{PP}_{t}$ & 0.48 & 0.49 & -0.50 & -0.20 \\
\hline \multirow{5}{*}{$\begin{array}{l}\text { Stratified } \\
n=52\end{array}$} & Surface Chl $a$ & 0.69 & 0.69 & -0.91 & -0.62 \\
\hline & Chl $a_{(0-50 \mathrm{~m})}$ & 0.72 & 0.72 & -0.88 & -0.60 \\
\hline & Chl $a_{t}$ & 0.17 & 0.17 & -0.56 & -0.79 \\
\hline & $\mathrm{PP}_{0-50 \mathrm{~m}}$ & 0.78 & 0.80 & -0.87 & -0.46 \\
\hline & $\mathrm{PP}_{t}$ & 0.78 & 0.79 & -0.85 & -0.42 \\
\hline
\end{tabular}

\subsection{Primary production}

Daily primary production in the euphotic zone $\left(\mathrm{PP}_{\mathrm{Zeu}}\right)$ of oligotrophic stations was higher in spring than in summer (on average $722 \pm 192$ and $457 \pm 242 \mathrm{mg} \mathrm{C} \mathrm{m}^{-2} \mathrm{~d}^{-1}$, respectively; Fig. 7). However, for mesotrophic stations, $\mathrm{PP}_{\mathrm{Zeu}}$ was significantly higher in summer than in spring (on average $1627 \pm 416$ and $1210 \pm 225 \mathrm{mg} \mathrm{C} \mathrm{m}^{-2} \mathrm{~d}^{-1}$, respectively). In summer, $\mathrm{PP}_{\mathrm{Zeu}}$ and $\mathrm{PP}_{0-50 \mathrm{~m}}$ correlated positively with $\mathrm{N}_{0-125 \mathrm{~m}}$ and $\mathrm{P}_{0-125 \mathrm{~m}}$, and inversely with SST and the stratification index $(n=32$, Table 2$)$. These correlations were weaker in spring $(n=32)$. $\mathrm{PP}_{\mathrm{Zeu}}$ and $\mathrm{PP}_{0-50 \mathrm{~m}}$ showed inverse correlations with SST at stratified stations (summer and spring combined) (Table 2, Fig. 6), and positive correlations with $\mathrm{N}_{0-125 \mathrm{~m}}$ and $\mathrm{P}_{0-125 \mathrm{~m}}$ (Table 2). The relationship between $\mathrm{PP}_{0-50 \mathrm{~m}}$ and SST was best described by an exponentially declining function (Fig. 6). There was a weak inverse correlation between productivity and the stratification index for stratified stations (Table 2). Productivity of non-stratified stations showed no correlations with $\mathrm{N}_{0-125 \mathrm{~m}}$ and $\mathrm{P}_{0-125 \mathrm{~m}}$ and SST (data not shown).

Cyanobacteria contributed up to $40 \%$ to the productivity of oligotrophic stations (group 1 and 2 combined; Figs. 6 , 8). At stratified stations (summer and spring combined), the contribution of cyanobacteria was inversely correlated with $\mathrm{N}_{0-125 \mathrm{~m}}$ and $\mathrm{P}_{0-125 \mathrm{~m}}$ and positively with SST, whereas no significant relationship was found for the stratification index
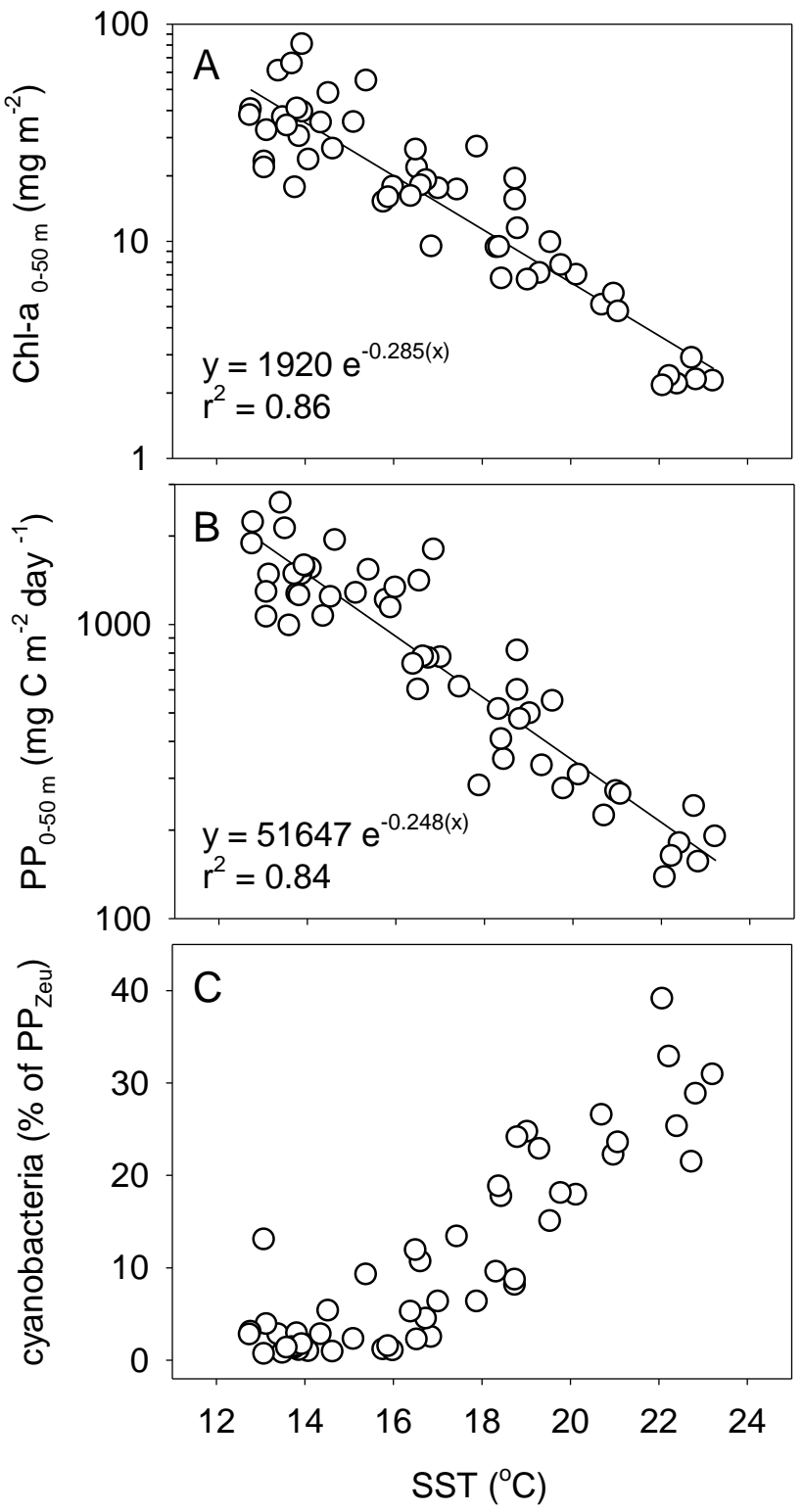

Fig. 6. (A) Relationship between depth-integrated (0-50 m) Chl $a$ (Chl $a_{0-50 \mathrm{~m}}$ ) and sea surface temperature (SST) for stratified stations from the summer and spring cruise $(n=52)$. (B) Relationship between depth-integrated $(0-50 \mathrm{~m})$ daily productivity $\left(\mathrm{PP}_{0-50 \mathrm{~m}}\right)$ and SST for stratified stations from the spring and summer cruises $(n=52)$. Note the exponential scales on the y-axes of graphs A and B. (C) Estimated productivity by cyanobacteria in the euphotic zone (group 1 and 2 combined) versus SST for stratified stations from the spring and summer cruises $(n=52)$.

(Table 3). In mesotrophic stations, productivity of cyanobacteria was of minor importance (Fig. 7). On average $30 \%$ of group 3 (prasinophytes, pelagophytes and cryptophytes) consisted of prasinophytes (data not shown). Group 3 showed a relatively stable contribution to productivity of stratified stations (on average $30 \%$ ). In non-stratified stations the 
Table 3. Spearman rank-order correlation coefficients of estimated contribution to primary production of group 1 (Prochlorococcus), group 2 (Synechococcus), group 1 and 2 combined (cyanobacteria), group 3 (prasinophytes, cryptophytes and pelagophytes), group 4 (haptophytes and dinophytes), and group 5 (diatoms) between nitrate $\left(\mathrm{N}_{0-125 \mathrm{~m}}\right)$ and inorganic phosphate $\left(\mathrm{P}_{0-125 \mathrm{~m}}\right)$ concentrations in the potential euphotic zone, sea surface temperature (SST), and density differences in the upper $200 \mathrm{~m}$ (density). Data are shown for stratified $(n=52)$ and non-stratified $(n=12)$ stations from spring and summer cruises.

\begin{tabular}{lrrrr}
\hline Stratified stations $(n=52)$ & $\mathrm{N}_{(0-125 \mathrm{~m})}$ & $\mathrm{P}_{(0-125 \mathrm{~m})}$ & $\mathrm{SST}$ & Density \\
\hline Group 1, 2 (Cyanobacteria) & $\mathbf{- 0 . 8 3}$ & $\mathbf{- 0 . 8 3}$ & $\mathbf{0 . 8 2}$ & 0.38 \\
Group 1 (Prochlorococcus) & $-\mathbf{0 . 7 7}$ & $-\mathbf{0 . 7 7}$ & $\mathbf{0 . 8 8}$ & 0.53 \\
Group 2 (Synechococcus) & $-\mathbf{0 . 7 9}$ & $-\mathbf{0 . 8 0}$ & $\mathbf{0 . 7 7}$ & 0.35 \\
Group 3 (Prasinophytes) & -0.01 & -0.03 & 0.11 & 0.07 \\
Group 4 (Haptophytes) & $\mathbf{0 . 6 0}$ & $\mathbf{0 . 6 0}$ & $-\mathbf{0 . 5 9}$ & -0.29 \\
Group 5 (Diatoms) & -0.09 & -0.23 & -0.26 & -0.28 \\
\hline Non-stratified stations $(n=12)$ & $\mathrm{N}_{(0-125 ~ \mathrm{~m})}$ & $\mathrm{P}_{(0-125 \mathrm{~m})}$ & $\mathrm{SST}$ & Density \\
\hline Group 3 (Prasinophytes) & $\mathbf{0 . 9 0}$ & $\mathbf{0 . 8 9}$ & $\mathbf{- 0 . 7 9}$ & -0.22 \\
Group 4 (Haptophytes) & $\mathbf{- 0 . 7 6}$ & $\mathbf{- 0 . 7 6}$ & $\mathbf{0 . 7 8}$ & 0.35 \\
Group 5 (Diatoms) & $\mathbf{- 0 . 7 3}$ & $\mathbf{- 0 . 7 1}$ & $\mathbf{0 . 5 9}$ & 0.01 \\
\hline
\end{tabular}

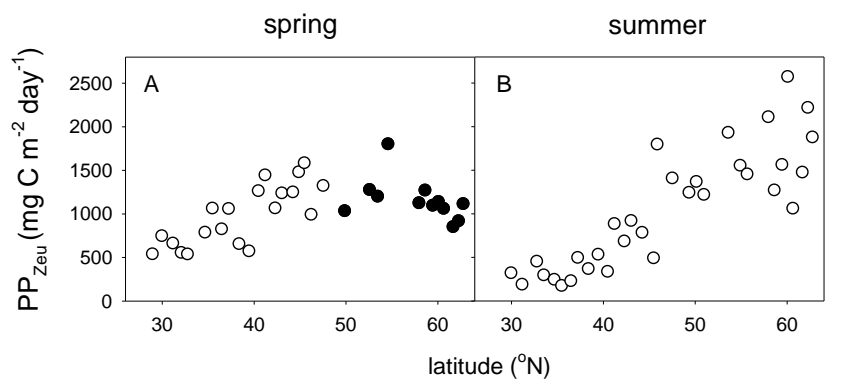

Fig. 7. Latitudinal changes in daily primary production in the euphotic zone $\left(\mathrm{PP}_{\mathrm{Zeu}}\right)$ during the spring $(\mathbf{A})$ and summer $(\mathbf{B})$ cruise. Productivity was estimated from in situ phytoplankton biomass and composition, light, light attenuation, and temperature using a biooptical model (see Methods section for details). Black symbols represent data from non-stratified stations.

contribution of group 3 increased up to $73 \%$ and showed positive correlations with $\mathrm{N}_{0-125 \mathrm{~m}}$ and $\mathrm{P}_{0-125 \mathrm{~m}}$ and an inverse correlation with SST (Table 3). Haptophytes were the most important contributor of group 4 (haptophytes, dinophytes) in spring $(91 \%)$ and summer $(75 \%)$. On average, group 4 accounted for $50 \%$ of the production in mesotrophic stations, whereas this was $37 \%$ in oligotrophic stations (Fig. 8). At stratified stations (summer and spring), the contribution of group 4 correlated positively with $\mathrm{N}_{0-125 \mathrm{~m}}$ and $\mathrm{P}_{0-125 \mathrm{~m}}$ and inversely with SST (Table 3). At non-stratified stations, group 4 showed inverse correlations with $\mathrm{N}_{0-125 \mathrm{~m}}$ and $\mathrm{P}_{0-125 \mathrm{~m}}$ and a positive correlation with SST. The contribution of diatoms to productivity (groups 5) was maximum at higher latitudes (up to $60 \%$ ) during the spring compared to summer (on average $8 \%$, Fig. 8). The contribution of diatoms to the productivity in stratified stations did not show correlations with $\mathrm{N}_{0-125 \mathrm{~m}}$ and $\mathrm{P}_{0-125 \mathrm{~m}}$ and SST (Table 3). At nonstratified stations, this group was inversely correlated with
$\mathrm{N}_{0-125 \mathrm{~m}}$ and $\mathrm{P}_{0-125 \mathrm{~m}}$ and positively correlated with SST (Table 3$)$.

\section{Discussion}

\subsection{Phytoplankton biomass and productivity in relation to SST, stratification, and nutrients}

The summer and spring comparison of open-ocean stations in the North Atlantic $\left(29-63^{\circ} \mathrm{N}\right)$ showed that phytoplankton biomass, productivity, and composition were correlated with $\mathrm{N}$ and $\mathrm{P}$ concentrations and SST. In the present study, the potential nutrient availability for phytoplankton was estimated by integration of nutrient concentrations over 0 $125 \mathrm{~m}\left(\mathrm{~N}_{0-125 \mathrm{~m}}\right.$ and $\left.\mathrm{P}_{0-125 \mathrm{~m}}\right)$. The positive correlations between $\mathrm{N}_{0-125 \mathrm{~m}}$ and $\mathrm{P}_{0-125 \mathrm{~m}}$ and $\mathrm{Chl} a$ and productivity suggested that open-ocean phytoplankton biomass and productivity were controlled by the availability of these nutrients in the investigated region. SST was inversely correlated with phytoplankton biomass and productivity and with $\mathrm{N}_{0-125 \mathrm{~m}}$ and $\mathrm{P}_{0-125 \mathrm{~m}}$. This suggests that SST is important in determining nutrient availability for phytoplankton by influencing vertical exchange with deeper nutrient-rich water. The relationships were stronger with SST than with the stratification index. In spring nutrient concentrations were more uncoupled from stratification, i.e., were less reflected by the differences in density. The correlation between SST and nutrients in non-stratified stations possibly reflects the relationship between SST and the depth of winter mixing. In addition, correlations between SST and phytoplankton biomass and productivity were weaker under the weakly and non-stratified conditions in spring. Moreover, the fraction of the phytoplankton biomass in the euphotic zone correlated with SST. Combined, this indicates that convective and wind mixing 


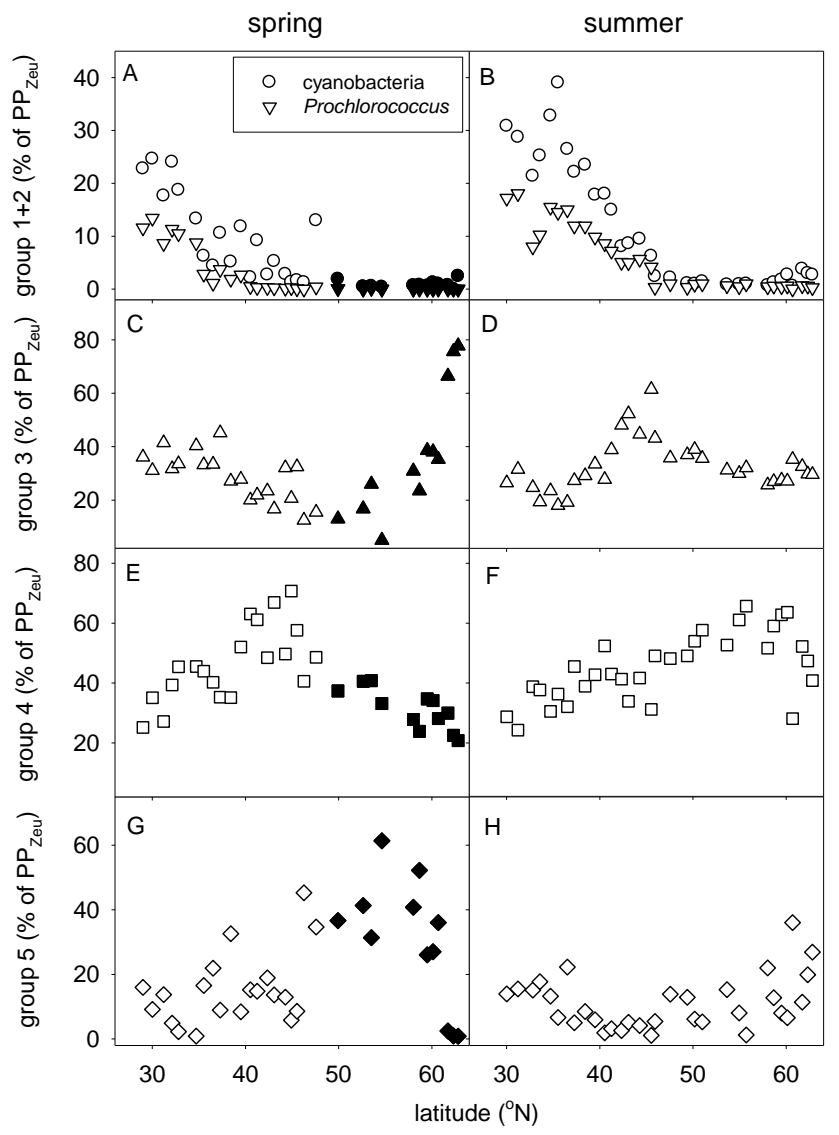

Fig. 8. Contributions to daily primary production in the euphotic zone of (A, B) group 1 (Prochlorococcus) and cyanobacteria (group $1+2),(\mathbf{C}, \mathbf{D})$ group 3 (prasinophytes, cryptophytes, pelagophytes), (E, F) group 4 (haptophytes, dinophytes), and (G, H) group 5 (diatoms) for the spring (A, C, E, G) and summer $(\mathbf{B}, \mathbf{D}, \mathbf{F}, \mathbf{H})$ cruises. Black symbols represent data from non-stratified stations.

exerted a stronger influence on the water column distribution of Chl $a$ in spring.

The inverse relationships between SST and near-surface phytoplankton biomass and $\mathrm{PP}_{0-50 \mathrm{~m}}$ for stratified stations suggest that within the SST range of $13-23^{\circ} \mathrm{C}$, North Atlantic open-ocean phytoplankton productivity co-varies with SST. If this also applies to interannual, and multidecadal SST changes, this would imply that anthropogenic warming of the ocean has a negative influence on phytoplankton biomass and productivity in the stratified open ocean within this temperature range. It should be noted that these correlations are not proof of causation. Nevertheless, the existence of correlations between SST, nutrient concentrations, phytoplankton PP and Chl $a$ in the surface oceans provide support for the hypothesis that SST influences nutrients in the open-ocean surface and thereby controls phytoplankton biomass, productivity and composition.

The relationship between productivity and SST in stratified stations indicated that a $0.5^{\circ} \mathrm{C}$ increase in SST would cause a $11 \%$ decline in daily productivity in the upper $50 \mathrm{~m}$. Gregg et al. (2003) reported a 6-7\% decline in annual productivity in the central and northern section of the North Atlantic from a 0.3 to $0.7^{\circ} \mathrm{C}$ SST increase. In addition, the response of Chl $a$ to SST observed in the present study suggested that a SST rise of $0.5^{\circ} \mathrm{C}$ would correspond to a $12-13 \%$ decline in near-surface Chl $a$ (surface $\mathrm{Chl} a$, Chl $a_{0-50 \mathrm{~m}}$ ) for stratified conditions between 13 to $23^{\circ} \mathrm{C}$. The nonlinear nature of the Chl $a$ and PP versus SST responses also indicates stronger responses can be expected in regions with lower SST, whereas responses are smaller in regions with higher SST. Previously, relationships between stratification and phytoplankton biomass and Chl $a$ for the oligotrophic North Atlantic and Pacific were not detected (Dave and Lozier, 2010; Lozier et al., 2011), whereas they were observed in remote sensing data with SST above $16^{\circ} \mathrm{C}$ (Behrenfeld et al., 2006).

\subsection{Stratification mediated shifts in phytoplankton biomass, productivity, and composition}

In spring, stations above $47^{\circ} \mathrm{N}$ showed minimal stratification, with potential density differences in the upper $200 \mathrm{~m}$ of $0.029 \pm 0.02 \mathrm{~kg} \mathrm{~m}^{-3}$. This is less than the reported $0.12 \mathrm{~kg} \mathrm{~m}^{-3}$ difference for eddy-driven stratification that preceded thermal stratification in the same region in 2008 (Mahadevan et al., 2012), but corresponds with values $\left(0.025 \mathrm{~kg} \mathrm{~m}^{-3}\right)$ where phytoplankton biomass accumulation in the upper $150 \mathrm{~m}$ was observed around New Zealand (Chiswell, 2011). At our non-stratified stations, we observed relatively low surface $\mathrm{Chl} a\left(0.7 \pm 0.3 \mathrm{mg} \mathrm{Chl} a \mathrm{~m}^{-3}\right)$, and up to $70 \%$ of the $\mathrm{Chl} a$ was below the euphotic zone. Comparable observations were reported during late winter-early spring by Backhaus et al. (2003) for the Icelandic Basin. Inevitably, the occurrence of phytoplankton below the euphotic zone will slow down growth rates of the phytoplankton standing stock. However, productivity estimates for the euphotic zone of non-stratified stations in the present study were not significantly different compared to those from stratified mesotrophic stations in spring.

Increased surface Chl $a$ in response to stratification of the water column represents the classical view of the spring bloom at mid- and higher latitudes (Sverdrup, 1953). However, the present study suggests that the pre-bloom conditions, with minimal stratification in the upper $200 \mathrm{~m}$ (beginning of May, latitude 49-62 $\mathrm{N}$ ), were more rich in terms of depth-integrated Chl $a\left(129 \pm 32 \mathrm{mg} \mathrm{Chl} a \mathrm{~m}^{-2}\right)$ compared with surface blooms at midlatitudes in spring $\left(44-45^{\circ} \mathrm{N}\right.$, up to $112 \pm 13 \mathrm{mg} \mathrm{Chl} a \mathrm{~m}^{-2}$ ) and surface blooms at higher latitudes in summer $\left(59-62^{\circ} \mathrm{N}\right.$,

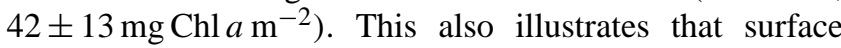
Chl $a$ concentration can be a poor indicator of phytoplankton standing stock, since surface $\mathrm{Chl} a$ was lower during pre-bloom conditions $\left(0.7 \pm 0.3 \mathrm{mg} \mathrm{Chl} a \mathrm{~m}^{-3}\right)$ compared with spring (1.8 $\left.\pm 0.3 \mathrm{mg} \mathrm{Chl} a \mathrm{~m}^{-3}\right)$ and summer 
$\left(1.3 \pm 0.3 \mathrm{mg} \mathrm{Chl} a \mathrm{~m}^{-3}\right)$ blooms. It was earlier observed that phytoplankton growth increased with increasing light in winter and early spring in the absence of stratification (Behrenfeld, 2010). This increase in Chl $a$ can be masked by the diluting effect of deep convective and wind-induced vertical mixing as proposed by Boss and Behrenfeld (2010).

Relationships between the contribution of taxonomic groups to productivity and SST were different for stratified and non-stratified stations. In the latter stations, productivity of group 3 (prasinophytes, cryptophytes) was inversely correlated with SST $\left(7-12^{\circ} \mathrm{C}\right)$, whereas group 4 (haptophytes) and 5 (diatoms) were positively correlated with SST. This suggested that temperature constrains productivity of the latter groups within this temperature range. In the present study, the nutrient-rich conditions associated with non-stratified stations supported significant diatom productivity (up to $60 \%$ ) above SST of $8^{\circ} \mathrm{C}$. After stratification, the relatively large and heavy diatoms typically become nutrient (Si) limited (Alkire et al., 2012). Furthermore, contraction of the mixed layer and the euphotic zone due to stratification traps a large amount of the phytoplankton in the dark ocean (Backhaus et al., 2003). Estimated class-specific productivity from SeaWiFS observations showed that the strongest productivity anomalies occurred in early spring in the temperate and subpolar North Atlantic, coinciding with diatom productivity (Uitz et al., 2010). Therefore, it can be expected that differences in annual primary production are in large part caused by variability in diatom productivity.

The nutrient concentrations in the euphotic zone of stratified stations were on average five times lower compared to those of the non-stratified stations. Furthermore, low N : P ratios indicated mostly $\mathrm{N}$-limitation in the upper euphotic zone $(0-50 \mathrm{~m})$ of stratified stations. This is consistent with factorial nutrient addition experiments in the oligotrophic North Atlantic that have identified $\mathrm{N}$ as the primary limiting nutrient (Davey et al., 2008; Moore et al., 2008). Therefore, the ability to compete for nutrients can be expected to be an important driver of changes in phytoplankton composition in the stratified North Atlantic. In the present study, changes in phytoplankton groups that contributed to primary production were observed along the latitudinal gradient in $\mathrm{N}_{0-125 \mathrm{~m}}$ and $\mathrm{P}_{0-125 \mathrm{~m}}$. Overall, the haptophyte pigment signature was dominant in spring and summer. Moreover, an inverse correlation was observed for the contribution of group 4 (dominated by haptophytes) and SST, whereas there was a positive correlation between SST and group 1 and 2 (cyanobacteria) in stratified stations. This suggests that increased SST will increase the contribution of less productive species, such as Prochlorococcus, at the expense of more productive species, such as haptophytes, at low and midlatitudes. Furthermore, the present study also suggests that haptophytes succeed diatoms after stratification in spring at higher latitudes. Therefore, earlier stratification in spring would prolong the growth season of haptophytes at higher latitudes in the North Atlantic Ocean.

\subsection{Productivity modeling and assumptions}

Reported productivity in the North Atlantic subtropical gyre varied between 100 and $350 \mathrm{mg} \mathrm{C} \mathrm{m}^{-2} \mathrm{~d}^{-1}$ (Morel et al., 1996; Marañón et al., 2000, 2003). Claustre et al. (2005) estimated daily primary production rates of $939 \pm 223$ and $393 \pm 80 \mathrm{mg} \mathrm{C} \mathrm{m}^{-2} \mathrm{~d}^{-1}$ for spring and summer, respectively, in the North Atlantic between 39 to $45^{\circ} \mathrm{N}$, which agrees with our estimates for this region. In the present study, $\mathrm{N}$ and $\mathrm{P}$ were not depleted in summer in the upper euphotic zone $(0-50 \mathrm{~m})$ of mesotrophic stations. Therefore, wind events can temporarily raise nutrient concentrations in the mixed layer in summer, making nutrient limitation less evident in these stations. At mesotrophic stations, reported productivity values do not show clear differences between summer and spring (500-2000 $\mathrm{mg} \mathrm{C} \mathrm{m}^{-2} \mathrm{~d}^{-1}$, Bury et al., 2001; Weeks et al., 1993), whereas our estimates are in the same range but suggest higher productivity in summer.

Our productivity calculations were significantly influenced by the assumed photoacclimation state of the phytoplankton. Inclusion of these differences was motivated by observed differences in $\mathrm{Chl} a$ specific absorption and recovery of PSII quantum yield from excess light, which both indicated acclimation to lower irradiance in spring. In the present study, Chl $a$ specific absorption was significantly lower $(37 \%)$ in spring compared to summer, as was also observed by Claustre et al. (2005). This may be caused by increased pigment packaging due to the presence of larger phytoplankton species such as diatoms. Furthermore, the relationships between Chl $a$ fluorescence (CTD) and HPLC determined Chl $a$ concentrations showed a decreased Chl $a$ specific fluorescence yield in spring as compared to summer (data not shown), providing additional evidence for seasonal differences in the Chl $a$ package effect. Most variability in $\mathrm{Chl} a$ specific absorption has been associated with changes in phytoplankton size structure (Bricaud et al., 2004). In the present study, reduced nutrient concentrations coincided with a shift to smaller phytoplankton species, which was also found in other studies (Agawin et al., 2000; Marañón et al., 2001; Bouman et al., 2011). Smaller species contain less Chl $a$ per cell and therefore show less pigment packaging (Ciotti et al., 2002). Therefore, changes in phytoplankton cell size may contribute to the observed nonlinear relationship between Chl $a$ and SST. However, acclimation to different light and nutrient conditions can also influence cellular Chl $a$ and Chl $a$ specific absorption, but the magnitude of these changes can vary among phytoplankton species (Geider et al., 1993; Kulk et al., 2011). Stronger turbulence in spring (Jurado et al., 2012b) may have reduced the light dose experienced by the phytoplankton, thereby increasing cellular pigment concentrations compared to the more stable summer conditions. Therefore, contributions of phytoplankton composition and photoacclimation on Chl $a$ specific absorption cannot be fully separated. However, recovery of PSII quantum yield from excess light provided additional 
evidence for acclimation to lower irradiance and less vertical structure in photosynthetic parameters in spring as compared to summer. Assuming low-light-acclimated phytoplankton in spring caused on average a $26 \%$ lower productivity for oligotrophic stations compared to the assumed vertical structure in photosynthetic parameters in summer. This underlines the importance of photoacclimation on the model results.

In the present study, several assumptions were made to model primary production from field measurements. Firstly, we applied a linear temperature correction to total modeled productivity. Typically, growth shows temperature dependence in specific oceanic phytoplankton species (Moore et al., 1995; Kulk et al., 2012). Eppley (1972) suggested that the temperature dependence of growth is exponential, with growth increasing with increasing temperature. However, compiled carbon fixation data and lab experiments suggest a linear response of productivity within the temperature range of $13-23^{\circ} \mathrm{C}$ (Behrenfeld et al., 1997; Montagnes and Franklin, 2001). Secondly, the model assumes that nutrient availability is reflected by differences in phytoplankton biomass and composition. This is in line with the observation that nutrient availability does not influence Chl $a$ specific net primary production in Dunaliella tertiolecta (Halsey, 2011). Moreover, phytoplankton turnover rates in the ocean are on the order of days, which would eliminate nutrient starved phytoplankton species from the community. Finally, the model assumes a sinusoidal irradiance distribution during the day and therefore does not include effects of cloud cover and/or vertical mixing. However, Kulk et al. (2011) showed that there were no significant effects of a dynamic irradiance regime on phytoplankton carbon fixation characteristics (under nutrient replete conditions). At last, the productivity model does not account for spectral irradiance changes at depth. Validation of the productivity calculations with field productivity estimates was not possible in the present study. Therefore, the current productivity estimates should be viewed as potential productivity estimates, rather than actual measurements. Overall, the model approach can expand the use of phytoplankton pigments and provided useful insight in group specific productivity.

\section{Conclusions}

Our results show an inverse relationship between phytoplankton productivity and biomass with SST for the stratified North Atlantic Ocean with SST between 13 and $23^{\circ} \mathrm{C}$. Furthermore, increasing SST was associated with a change in phytoplankton species composition from haptophytes to cyanobacteria at mid- and low latitudes. Since increases in North Atlantic SST are expected for the coming decades, phytoplankton may respond accordingly. Responses to a future temperature rise are more likely to be observed in high latitude Chl $a$ and productivity due to the nonlinear relationship with SST. Increasing SST has been suggested to mediate different effects on phytoplankton biomass in subtropical (less productivity) and subpolar regions (increased productivity due to a longer growth season) in the North Atlantic. However, our data showed the highest depth-integrated Chl $a$ at higher latitude non-stratified stations in spring, suggesting that phytoplankton blooms can start under minimal stratification. This indicated that possible earlier onset of stratification (and surface blooming) would not necessarily result in a longer and more productive season. In contrast, delayed stratification may prolong the growth season of diatoms, the most productive phytoplankton group that contributes significantly to carbon export into the deep ocean, whereas earlier stratification may expand the contribution of haptophytes at the expense of diatoms.

\section{Supplementary material related to this article is available online at: http://www.biogeosciences.net/10/ 4227/2013/bg-10-4227-2013-supplement.pdf.}

Acknowledgements. We thank the captain and crew of R/V Pelagia and the support of NIOZMRF onshore and onboard. The cruise was supported by the Research Council for Earth and Life Sciences (ALW), with financial aid from the Netherlands Organization for Scientific Research (NWO). This work is part of Stratiphyt subproject 2 (project number 839.08.422), subsidized by ALW/NWO.

Edited by: E. Marañón

\section{References}

Agawin, N. S. R., Duarte, C. M., and Agustí, S.: Nutrient and temperature control of the contribution of picophytoplankton to phytoplankton biomass and production, Limnol. Oceanogr.,45, 591600, 2000.

Alkire M. B., Asaro, E., Lee, C., Perry, M. J., Gray, A., Cetinic, I., Briggs, N., Rehma, E., Kallin, E., Kaiser, J., and GonzálezPosada, A.: Estimates of net community production and export using high-resolution, Lagrangian measurements of $\mathrm{O}_{2}, \mathrm{NO}_{3}$, and POC through the evolution of a spring diatom bloom in the North Atlantic, Deep-Sea Res. Pt. I, 64, 157-174, 2012.

Backhaus, J. O., Hegseth, E. N., Wehde, H., Irigoien, X., Hatten, $\mathrm{K}$., and Logemann, K.: Convection and primary production in winter, Mar. Ecol.-Prog. Ser., 251, 1-14, 2003.

Baudoux, A. C., Veldhuis, M. J. W., Noordeloos, A. A. M., van Noort, G., and Brussaard, C. P. D.: Estimates of virus- vs. grazing induced mortality of picophytoplankton in the North Sea during summer, Aquat. Microb. Ecol., 52, 69-82, 2008.

Behrenfeld, M. J.: Abandoning Sverdrup's critical depth hypothesis, Ecology, 91, 977-989, 2010.

Behrenfeld, M. J. and Falkowski, P. G.: Photosynthetic rates derived from satellite-based chlorophyll concentrations, Limnol. Oceanogr., 42, 1-20, 1997.

Behrenfeld, M. J., O’Malley, R. T., Siegel, D. A., McClain, C. R., Sarmiento, J. L., Feldman, G. C., Milligan, A. J., Falkowski, P. G., Letelier, R. M., and Boss, E. S.: Climate-driven trends in contemporary ocean productivity, Nature, 444, 752-755, 2006. 
Boss, E. and Behrenfeld, M. J.: In situ evaluation of initiation of the North Atlantic phytoplankton bloom, Geophys. Res. Lett., 37, $1-5,2010$.

Bouman, H. A., Ulloa, O., Barlow, R., Li, W. K. W., Platt, T., Zwirglmaier, K., and Sathyendranath, S.: Water-column stratification governs the community structure of subtropical marine picophytoplankton, Environ. Microb. Rep., 3, 473-482, 2011.

Boyce, D. G., Lewis, M. R. and Worm, B.: Global phytoplankton decline over the past century, Nature, 466, 752-755, 2010.

Bricaud, A., Claustre, H., Ras, J., and Oubelkheir, K.: Natural variability of phytoplanktonic absorption in oceanic waters: influence of the size structure of algal populations, J. Geophys. Res., 109, C11010, doi:10.1029/2004JC002419, 2004.

Bury, S. J., Boyd, P. W., Preston, T., Gavidge, G., and Owens, N. J. P.: Size-fractionated primary production and nitrogen uptake during a North Atlantic phytoplankton bloom: implications for carbon export estimates, Deep-Sea Res. Pt. I, 48, 689-720, 2001.

Chaves, F. P., Messié, M., and Pennington, J. T.: Marine primary production in relation to climate variability and change, Ann. Rev. Marine Sci., 3, 227-260, 2010.

Chisholm, S. W. and Morel, F. M. M.: What controls phytoplankton production in nutrient-rich areas of the open sea?, Limnol. Oceanogr., 36, 1507-1511, 1991.

Chiswell, S. M.: Annual cycles and spring blooms in phytoplankton: don't abandon Sverdrup completely, Mar. Ecol.-Prog. Ser., 443, 39-50, 2011.

Ciotti, A. M., Lewis, M. R., and Cullen, J. J.: Assessment of the relationships between dominant cell size in natural phytoplankton communities and the spectral shape of the absorption coefficient, Limnol. Oceanogr., 47, 404-417, 2002.

Claustre, H., Babin, M., Merien, D., Ras, J., Primeur, L., Dallot, S., Prasil, O., Dousova, H., and Moutin, T.: Towards a taxon-specific parameterization of bio-optical models of primary production: a case study in the North Atlantic, J. Geophys. Res., 110, C07S12, doi:10.1029/2004JC002634, 2005.

Dave, A. C. and Lozier, M. S.: Local stratification control of marine productivity in the subtropical North Pacific, J. Geophys. Res., 115, 1-16, doi:10.1029/2010JC006507, 2010.

Davey, M., Tarran, G. A., Mills, M. M., Ridame, C., Geider, R. J., and LaRoche, J.: Nutrient limitation of picophytoplankton photosynthesis and growth in the tropical North Atlantic, Limnol. Oceanogr., 53, 1722-1733, 2008.

De Boyer Montegut, C., Madec, G., Fischer, A. C., Lazar, A., and Ludicone, D.: Mixed layer depth over the global ocean: an examination of profile data and profile-based climatology, J. Geophys. Res., 109, C12003, doi:10.1029/2004JC002378, 2004.

Drinkwater, K. F., Belgrano, A., Borja, A., Conversi, A., Edwards, M., Greene, C. H., Ottersen, G., Pershing, A. J., and Walker, H.: The response of marine ecosystems to climate variability associated with the North Atlantic Oscillation, in: The North Atlantic Oscillation, edited by: Hurrell, J. W., Kushnir, Y., Ottersen, G., and Visbeck, M., American Geophysical Union, Washington, DC, 211-234, 2003.

Dutkiewicz, S., Follows, M., Marshall, J., and Gregg, W. W.: Interannual variability of phytoplankton abundances in the North Atlantic, Deep-Sea Res. Pt. II, 48, 2323-2344, 2001.

Enfield, D. B., Mestas-Nunez, A. M., and Trimble, P. J.: The Atlantic multidecadal oscillation and its relation to rainfall and river flows in the continental US, Geophys. Res. Lett., 28, 2077-2080,
2001.

Eppley, R. W.: Temperature and phytoplankton growth in the sea, Fish. Bull., 70, 1063-1085, 1972.

Geider, R. J., LaRoche, J., Greene, R. M., and Olaizola, M.: Response of the photosynthetic apparatus of Phaeodactylum tricornutum (Bacillariophyceae) to nitrate, phosphate, or iron starvation, J. Phycol., 29, 755-766, 1993.

Gleckler, P. J., Santer, D. B., Domingues, C. M., Pierce, D. W., Barnett, T. P., Church, J. A., Taylor, K. E., Boyer, M., Ishii, M., and Caldwell, P. M.: Human-induced global ocean warming on multidecadal timescales, Nat. Clim. Change, 2, 524-529, doi:10.1038/NCLIMATE1553, 2012.

Gregg, W. W., Conkright, M. E., Ginoux, P., O'Reilly, J. E., and Casey, N. W.: Ocean primary production and climate: global decadal changes, Geophys. Res. Lett., 30, 1809, doi:10.1029/2003GL016889, 2003.

Halsey, K. H., Milligan, A. J., and Behrenfeld, M. J.: Linking timedependent carbon-fixation efficiencies in Dunaliella Tertiolecta (Chlorophyceae) to underlying metabolic pathways, J. Phycol., 47, 66-76, 2011.

Hofmann, M., Worm, B., Rahmstorf, S., and Schellnhuber, H. J.: Declining ocean chlorophyll under unabated anthropogenic $\mathrm{CO}_{2}$ emissions, Environ. Res. Lett., 6, 1-7, 2011.

Hooker, S. B., Van Heukelem, L., Thomas, C. S., Claustre, H., Ras J., Schlüter, L., Clementson, L., Van der Linde, D., Eker-Develi, E., Berthon, J., Barlow, R., Sessions, H., Ismail, H., and Perl, J.: The third SeaWiFS HPLC Analysis Round-Robin Experiment (SeaHARRE-3), NASA Tech. Memo 2009-215849, NASA Goddard Space Flight Center, Greenbelt, Maryland, USA, 2009.

Johnson, Z. I., Zinser, E. R., Coe, A., McNulty, N. P., Woodward, E. M. S., and Chisholm, S. W.: Niche partitioning among Prochlorococcus ecotypes along ocean-scale environmental gradients, Science, 311, 1737-1740, 2006.

Jurado, E., van der Woerd, H. J., and Dijkstra, H. A.: Microstructure measurements along a quasi-meridional transect in the northeast Atlantic, J. Geophys. Res., 117, C04016, doi:10.1029/2011JC007137, 2012a.

Jurado, E., Dijkstra, H. A., and van der Woerd, H. J.: Microstructure observations during the spring 2011 STRATIPHYT-II cruise in the northeast Atlantic, Ocean Sci., 8, 945-957, doi:10.5194/os8-945-2012, 2012.

Kirk, J. T. O.: Light and photosynthesis in aquatic environments, in: Advances in Photosynthesis and Respiration, Cambridge University Press, 5, 321-346, 1994.

Kulk, G., van de Poll, W. H., Visser, R. J. W., and Buma, A. G. J.: Distinct differences in photoacclimation potential between prokaryotic and eukaryotic oceanic phytoplankton, J. Exp. Mar. Biol. Ecol., 398, 63-72, 2011.

Kulk, G., de Vries, P., van de Poll, W. H., Visser, R. J. W., and Buma, A. G. J.: Temperature dependent growth and photophysiology of prokaryotic and eukaryotic oceanic picophytoplankton, Mar. Ecol.-Prog. Ser., 466, 43-55, 2012.

Laviale, M. and Neveux, J.: Relationships between pigment ratios and growth irradiance in 11 marine phytoplankton species, Mar. Ecol.-Prog. Ser., 425, 63-77, 2011.

Li, W. K. W.: Primary production of prochlorophytes, cyanobacteria, and eukaryotic ultraphytoplankton measurements from flowcytometric sorting, Limnol. Oceanogr., 39, 169-175, 1994. 
Litchman, E., Klausmeier, C. A., Schofield, O. M., and Falkowski, P. G.: The role of functional traits and trade-offs in structuring phytoplankton communities: scaling from cellular to ecosystem level, Ecol. Lett., 10, 1170-1181, 2007.

Lozier, S. M., Dave, A. C., Palter, J. B., Geber, L. M., and Barber, R. T.: On the relationship between stratification and primary production in the North Atlantic, Geophys. Res. Lett., 38, 1-6, doi:10.1029/2011GL049414, 2011.

Mackey, M. D., Higgins, H. W., Mackey, D. J., and Wright, S. W.: CHEMTAX - a program for estimating class abundances from chemical markers: application to HPLC measurements of phytoplankton, Mar. Ecol.-Prog. Ser., 144, 265-283, 1996.

Mahadevan A., D’Asaro, E. D., Lee, C., and Perry, M. J.: Eddydriven stratification initiates North Atlantic spring phytoplankton blooms, Science, 337, 54-58, 2012.

Marañón, E., Patrick, H., Holligan, M. M., Varela, B., Mourin, A. J., and Bale Maran, E.: Basinscale variability of phytoplankton biomass, production and growth in the Atlantic Ocean, Deep-Sea Res. Pt. I, 47, 825-857, 2000.

Marañón, M., Holligan, P. M., Barciela, R., Gonzalez, N., Mourino, B., Pazo, M. J., and Varela, M.: Patterns of phytoplankton size structure and productivity in contrasting open-ocean environments. Mar. Ecol.-Prog. Ser., 216, 43-56, 2001.

Marañón, E., Behernfeld, M. J., Gonzalez, N., Mourino, B., and Zubkov, M. V.: High variability of primary production in oligotrophic waters of the North Atlantic Ocean: uncoupling from phytoplankton biomass and size structure, Mar. Ecol.-Prog. Ser., 257, 1-11, 2003.

Martin, P., Lampitt, R. S., Perry, M. J., Sanders, R., Lee, C., and D'Asaro, E.: Export and mesopelagic particle flux during a North Atlantic spring diatom bloom, Deep-Sea Res. Pt. I, 58, 338-349, 2011.

Mojica, K. D. A., van de Poll, W. H., Kehoe, M. J., Witte, H., Huisman, J., Timmermans, K. R., Buma, A. G. J., van der Woerd, H. J., Dijkstra, H. A., and Brussaard, C. P. D.: Phytoplankton abundance, size and community composition as a function of vertical stratification in the Northeast Atlantic Ocean, Limnol. Oceanogr., submitted, 2013.

Montagnes, D. J. S. and Franklin, D. J.: Effect of temperature on diatom volume, growth rate, and carbon and nitrogen content: reconsidering some paradigms, Limnol. Oceanogr., 46, 20082018, 2001.

Moore, C. M., Mills, M. M., Langois, R., Milne, A., Achterberg, E. P., LaRoche, J., and Geider, R. J.: Relative influence of nitrogen and phosphorous availability on phytoplankton physiology and productivity in the oligotrophic sub-tropical North Atlantic Ocean, Limnol. Oceanogr., 53, 291-305, 2008.

Moore, L. R., Goericke, R., and Chisholm, S. W.: Comparative physiology of Synechococcus and Prochlorococcus: influence of light and temperature on growth, pigments, fluorescence and absorptive properties, Mar. Ecol.-Prog. Ser., 116, 259-275, 1995.

Morel A., Antoine, D., Babin, M., and Dandonneau, Y.: Measured and modeled primary production in the northeast Atlantic (EUMELI JGOFS program): the impact of natural variations in photosynthetic parameters on model predictive skill, Deep-Sea Res. Pt. I, 43, 1272-1304, 1996.

Platt, T., Gallegos, C. L., and Harrison, W. G.: Photoinhibition of photosynthesis in natural assem blages of marine-phytoplankton, J. Mar. Res., 38, 687-701, 1980.
Polovina, J. J., Howell, E. A., and Abecassis, M.: Ocean's least productive waters are expanding, Geophys. Res. Lett., 35, L03619, doi:10.1029/2007GL031745, 2008.

Racault, M. F., Le Quéré, C., Buitenhuis, E., Sathyendranath, S., and Platt T.: Phytoplankton phenology in the global ocean, Ecol. Indic., 14, 152-163, 2012.

Richardson, A. J. and Schoeman, D. S.: Climate impact on plankton ecosystems in the Northeast Atlantic, Science, 305, 1609-1612, 2004.

Siegel, D. A., Doney, S. C., and Yoder, Y. A.: The North Atlantic Spring bloom and Sverdrups's critical depth hypothesis, Science, 296, 730-733, 2002.

Steinacher, M., Joos, F., Frölicher, T. L., Bopp, L., Cadule, P., Cocco, V., Doney, S. C., Gehlen, M., Lindsay, K., Moore, J. K., Schneider, B., and Segschneider, J.: Projected 21st century decrease in marine productivity: a multi-model analysis, Biogeosciences, 7, 979-1005, doi:10.5194/bg-7-979-2010, 2010.

Sverdrup, H.: On conditions of vernal blooming of phytoplankton, J. Conseil, 18, 287-295, 1953.

Tassan, T. and Ferrari, G. M.: Proposal for the measurement of backscatter and total scattering by mineral particles suspended in water, Appl. Optics, 34, 8345-8353, 1995.

Taylor, J. and Ferrari, R.: Shutdown of turbulent convection as a new criterion for the onset of spring phytoplankton blooms, Limnol. Oceanogr., 56, 2293-2307, 2011.

Ting, M., Kushnir, Y., Seager, R., and Li, C.: Forced and internal twentieth-century SST trends in the North Atlantic, J. Climate, 22, 1469-1481, 2009.

Uitz, J., Huot, Y., Bruyant, F., Babin, M., and Claustre, H.: Relating phytoplankton photophysiolofical properties to community structure on large scales, Limnol. Oceanogr., 53, 614-630, 2008.

Uitz, J., Claustre, H., Gentili, B., and Stramski, D.: Phytoplankton class-specific primary production in the world's oceans: seasonal and interannual variability from satellite observations, Global Biogeochem. Cy., 24, 1-19, 2010.

Van de Poll, W. H., Alderkamp, A. C., Janknegt P. J., Roggeveld J., and Buma, A. G. J.: Photoacclimation modulates effects of excessive photosynthetically and ultraviolet radiation in a temperate and an Antarctic marine diatom, Limnol. Oceanogr., 51, 1239-1248, 2006.

Van de Poll, W. H., Lagunas, M., de Vries, T., Visser, R. J. W., and Buma A. G. J.: Non-photochemical quenching of chlorophyll fluorescence and xanthophyll cycle responses after excess PAR and UVR in Chaetoceros brevis, Phaeocystis antarctica and coastal Antarctic phytoplankton, Mar. Ecol.-Prog. Ser., 426, 119-131, 2011.

Weeks, A., Conte, H. M., Harris, R. P., Bedo, A., Bellan, I., Burkhill, P. H., Edwards, E. S., Habour, D. S. Kennedy, H., Llewellyn, C., Mantoura, R. F. C., Morales, C. E., Pomroy, A. J., and Turley, C. M.: The physical and chemical environment and changes in community structure associated with bloom evolution: the Joint Global Flux Study North Atlantic Bloom Experiment, Deep-Sea Res. Pt. II, 40, 347-368, 1993.

Zapata, M., Jeffrey, S. M., Wright, S. M., Rodriguez, F., Garrido, J. L., and Clementson, L.: Photosynthetic pigments in 37 species (65 strains) of Haptophyta: implications for oceanography and chemotaxonomy, Mar. Ecol.-Prog. Ser., 270, 83-102, 2004. 